\title{
Tracer Study of Nueva Ecija University of Science and Technology Graduates (Atate Campus)
}

\author{
Engr. Rolando P. Corpuz
}

Assistant Professor IV, Director, Atate Campus, Nueva Ecija University of Science and Technology, Philippines

\begin{abstract}
The essence of a higher education institution or university is to produce employable graduates. This study described the profiles of the graduates of batch 2018 and 2019 (Bachelor of Science in Information Technology, Bachelor of Science in Business Administration, and Bachelor of Science in Entrepreneurship) of NEUST Atate Campus in terms of Sex, Employment Status, Year Hired, and Monthly Salary. It also described the work location, and list of agencies where the graduates of NEUST Atate Campus were employed. The descriptive survey method of research was used in this study. A total of 118 graduates from NEUST Atate Campus which comprises of 65 BSIT (27 graduates of year 2018 and 38 graduates of year 2019), 24 BSBA (Batch 2018), and 29 BSEntre (Batch 2019) were surveyed. Based from the results of this tracer study, it can be seen that only more than half of the graduates were already employed. The employed graduates are working in their nearby cities/towns and few are working abroad. It is then recommended by the researcher to have a follow up study on the status of the employment of their graduates. The follow up study should include other information would be beneficial for the improvement of the programs and activities related to the graduates of their alma mater, Nueva Ecija University of Science and Technology. A study must include the employed graduates' position in the agency, their challenging experiences while applying on their work, do their current work aligned with their graduated courses, and the like. This should also include an evaluation of the agencies on the graduates' work attitude and behavior. Thus, evaluating the quality of graduates the university is producing yearly based on the university's mission.
\end{abstract}

Keywords - Tracer Study, Nueva Ecija University, higher education institution.

\section{INTRODUCTION}

The essence of a higher education institution or university is to produce employable graduates. It measures the individual institution's success and potential to deliver work-ready students (Latif \& Bahroom, 2010). New and emerging innovations are questioning the conventional teaching and learning cycle, and how things are organized and operated (Macatangay, 2013).

High Education offers longitudinal systemic data on jobs and occupation, the essence of the job and related skills, and knowledge on their students ' personal orientation and experience (Millington, 2008). Further, the Philippine Qualifications System requires department roles such as DepEd, CHED, TESDA, PRC and DOLE to review learning requirements in basic education, technical skills growth and higher education and in the coordination of licensing exams (Philippines Executive Order no. 83, s, 2012). This is essential to ensure that learners are introduced to career opportunities and, more specifically, work experience early in their college preparation and throughout (Cosser, 2003).

With the gradual increase in the number of college graduates, job opportunities have become highly competitive for students. Most universities have the strategy of improving existing connections and creating new pathways to the work world (Ramirez et al., 2014). Through developing relationships when communicating with clients, the students learned how to connect and sell effectively, and learned to meet deadlines for inventory distribution and acceptable loan payments, respectively, as built marketing and management skills (Santos, 2020).

Many universities have the philosophy of strengthening existing connections and building new bridges to the industry. In view of this, the NEUST Mission is to develop new knowledge and technologies and transform human 
resources into productive citizenry to bring about development impact to local and international communities (NEUST, 2020).

The information gained from these can be used by the graduate alma mater and other educational partners for curriculum development and other new changes by administering and evaluating a survey on the cohort of graduates from a given school, occupation, specialty, level of education, their work characteristics, qualifications and skill development (Gines, 2014).

In view of the foregoing insights, the researcher would like to assess the graduates in terms of employability as a metric of the institution's Mission. The results of the study will also provide information for institutions' linkages that may help in terms of partnership.

\section{OBJECTIVES OF THE STUDY}

This study described the profiles of the graduates of batch 2018 and 2019 (Bachelor of Science in Information
Technology, Bachelor of Science in Business Administration, and Bachelor of Science in Entrepreneurship) of NEUST Atate Campus in terms of Sex, Employment Status, Year Hired, and Monthly Salary. It also described the work location, and list of agencies where the graduates of NEUST Atate Campus were employed.

\section{METHODOLOGY}

The descriptive method of research was used in this study because it involves description, recording, analysis and interpretation of condition that really exists. It is appropriate to use descriptive method in gathering information about the present existing condition (Creswell, 2014). A total of 118 graduates from NEUST Atate Campus which comprises of 65 BSIT (27 graduates of year 2018 and 38 graduates of year 2019), 24 BSBA (Batch 2018), and 29 BSEntre (Batch 2019) were surveyed. This study used survey research since it integrates scientific methods through critical analysis and evaluation of source materials, analysis and interpretation of data, and generalization and prediction (Salaria, 2012).

\section{RESULTS AND DISCUSSIONS}

Table 1. Profile of the Batch 2018 Graduates of the Nueva Ecija University of Science and Technology (Atate Campus)

\begin{tabular}{|c|c|c|c|c|c|}
\hline & & \multicolumn{2}{|c|}{$* \mathbf{B S B A}$} & \multicolumn{2}{|c|}{ *BSIT } \\
\hline & & $f$ & $\%$ & $f$ & $\%$ \\
\hline \multicolumn{6}{|l|}{ Sex } \\
\hline Male & & 8 & 33.33 & 15 & 62.56 \\
\hline Female & & 16 & 66.67 & 12 & 44.44 \\
\hline & Total & 24 & 100.00 & 27 & 100.00 \\
\hline
\end{tabular}

\section{Employment Status}

Employed

Unemployed

Untracked

Year Hired (for employed)

2018

2019

$\begin{array}{ccccc} & 14 & 58.33 & 19 & 70.38 \\ & 10 & 41.67 & 4 & 14.81 \\ & - & - & 4 & 14.81 \\ \text { Total } & \mathbf{2 4} & \mathbf{1 0 0 . 0 0} & \mathbf{2 7} & \mathbf{1 0 0 . 0 0}\end{array}$




\section{Monthly Salary (in Pesos)(for employed)}

20,001 and above

$\begin{array}{ccccc}2 & 14.29 & - & - \\ & - & - & - & - \\ - & - & 2 & 10.53 \\ & - & - & 5 & 26.31 \\ & 2 & 14.29 & 9 & 47.37 \\ & 10 & 71.42 & 3 & 15.79 \\ & - & - & - & - \\ \text { Total } & \mathbf{1 4} & \mathbf{1 0 0 . 0 0} & \mathbf{1 9} & \mathbf{1 0 0 . 0 0}\end{array}$

*Note: BSBA - Bachelor of Science in Business Administration (major Entrepreneurship )

BSIT - Bachelor of Science in Information Technology

Table 1 shows the profile of Batch 2018 graduates of Nueva Ecija University of science and Technology (Atate Campus).

For BSBA, there were a total of 24 graduates composed of 8 males (33.33\%) and 16 females (66.67\%). 14 out of 24 or 58.33 percent were already employed and the remaining 10 or 41.67 percent of graduates were not yet employed. For all the employed graduates, $10(71.43 \%)$ were hired in 2018 and 4 (28.57\%) were hired in 2019. Their monthly salary is ranging from 5,001 and above (in Pesos) where 10 out of 14 or 71.42 percent of the employed graduates receive their monthly salary ranging from 5,001 to 8,000 pesos.
For BSIT, 15 males (62.56 \%) and 12 females (44.44 $\%$ ) for a total of 27 students have graduated in this course. Their employment status showed that 19 out of 27 (70.38\%) were already employed, $4(14.81 \%)$ were unemployed and the other $4(14.81 \%)$ were untracked or were not able to respond the tracer study during the conduct of this research. These employed graduates were hired in 2018 (13 or 68.42\%) and in 2019 (6 or $31.58 \%$ ). Their monthly salary is ranging from 5,001 up to 17,000 pesos where almost half of the employed graduates $(47.37 \%)$ receive their monthly salary ranging from 8,001 to 11,000 pesos.

Table 2. Profile of the Batch 2019 Graduates of the Nueva Ecija University of Science and Technology (Atate Campus)

\begin{tabular}{|c|c|c|c|c|c|}
\hline & & \multicolumn{2}{|c|}{ *BS Entrep } & \multicolumn{2}{|c|}{ *BSIT } \\
\hline & & $f$ & $\%$ & $f$ & $\%$ \\
\hline \multicolumn{6}{|l|}{$\operatorname{Sex}$} \\
\hline Male & & 7 & 24.14 & 23 & 62.56 \\
\hline Female & & 22 & 75.86 & 15 & 44.44 \\
\hline & Total & 29 & 100.00 & 38 & 100.00 \\
\hline \multicolumn{6}{|l|}{ Employment Status } \\
\hline Employed & & 14 & 48.28 & 20 & 70.38 \\
\hline Unemployed & & 11 & 37.93 & 14 & 14.81 \\
\hline Untracked & & 4 & 13.79 & 4 & 14.81 \\
\hline
\end{tabular}




\section{$\begin{array}{lllll}\text { Total } & 29 & 100.00 & 38 & 100.00\end{array}$}

Year Hired (for employed)

2019

$\begin{array}{lllll} & 14 & 100.00 & 20 & 100.00 \\ \text { Total } & \mathbf{1 4} & \mathbf{1 0 0 . 0 0} & \mathbf{2 0} & \mathbf{1 0 0 . 0 0}\end{array}$

Monthly Salary (in pesos)(for employed)

20,001 and above

$17,001-20,000$

$14,001-17,000$

$11,001-14,000$

$8,001-11,000$

$5,001-8,000$

$\begin{array}{llll}- & - & 1 & 5.00\end{array}$

5,000 and below

$\begin{array}{lllll}\text { Total } & 14 & 100.00 & 20 & 100.00\end{array}$

*Note: BS Entrep - Bachelor of Science in Entrepreneurship

BSIT - Bachelor of Science in Information Technology

Table 2 shows the profile of Batch 2018 graduates of Nueva Ecija University of science and Technology (Atate Campus).

For BS Entrep, there were a total of 29 graduates composed of 7 males $(24.14 \%)$ and 22 females (75.86 \%). Of all these graduates, 14 out of 29 or 48.28 percent were already employed, 11 or 37.93 percent of graduates were not yet employed, and the remaining 4 or 13.79 percent were untracked or were not able to respond during the conduct of this tracer study. These employed graduates were all hired in 2019 which could possibly be month/s right after their graduation. Their monthly salary is ranging from 5,001 up to 11,000 pesos, in general.
For BSIT, 23 males (60.53\%) and 15 females (39.47 $\%)$ for a total of 39 students have graduated in this course. Their employment status showed that 20 out of 39 (52.63\%) were already employed, 14 (36.84\%) were unemployed and the other $4(10.53 \%)$ were untracked or were not able to respond the tracer study during the conduct of this research. These employed graduates were all hired in 2019 which could possibly be month/s right after their graduation. Their monthly salary is ranging from 5,001 and above (in pesos) where majority of the employed graduates $(47.37 \%)$ receive their monthly salary ranging from 5,001 to 8,000 pesos.

Table 3. Work Locations of the Batch 2018 and 2019 Employed Graduates of Nueva Ecija University and Science and Technology (Atate Campus)

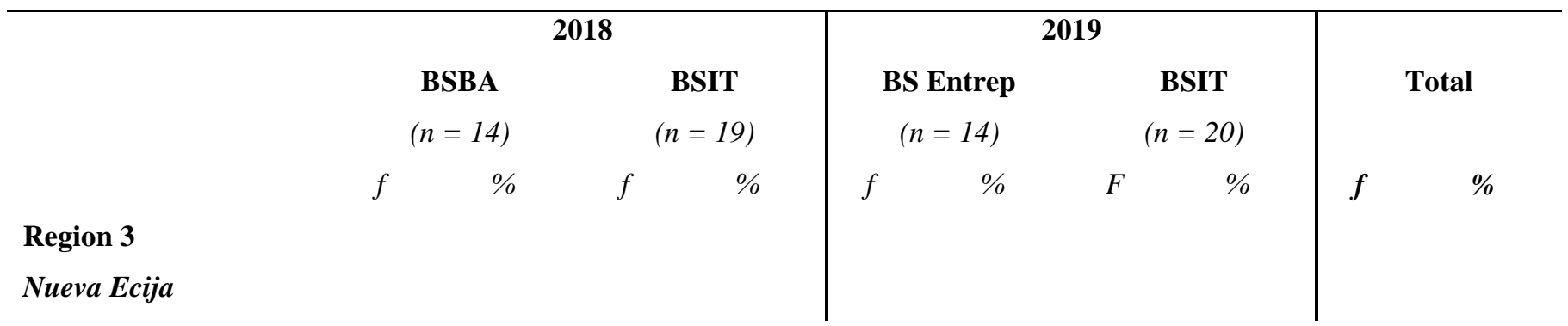

ISSN: $2456-7620$ 


\begin{tabular}{|c|c|c|c|c|c|c|c|c|c|c|}
\hline Bongabon & 4 & 28.57 & - & - & 1 & 7.14 & - & - & 5 & 7.46 \\
\hline Cabanatuan & 3 & 21.44 & 9 & 47.37 & 7 & 50.00 & 5 & 25.00 & 24 & 35.82 \\
\hline Cabiao & 1 & 7.14 & - & - & - & - & - & - & 1 & 1.49 \\
\hline Laur & 1 & 7.14 & - & - & - & - & - & - & 1 & 1.49 \\
\hline Palayan & 1 & 7.14 & 2 & 10.53 & 3 & 21.44 & 7 & 35.00 & 13 & 19.40 \\
\hline Talavera & - & - & - & - & - & - & 1 & 5.00 & 1 & 1.49 \\
\hline Bulacan & 2 & 14.29 & - & - & - & - & - & - & 2 & 2.99 \\
\hline Pampanga & - & - & 1 & 5.26 & - & - & 1 & 5.00 & 2 & 2.99 \\
\hline \multicolumn{11}{|l|}{ Outside Region 3} \\
\hline Cainta & - & - & - & - & - & - & 1 & 5.00 & 1 & 1.49 \\
\hline Calaocan & - & - & - & - & - & - & 2 & 10.00 & 2 & 2.99 \\
\hline Laguna & - & - & 1 & 5.26 & - & - & - & - & 1 & 1.49 \\
\hline Makati & - & - & 2 & 10.53 & 1 & 7.14 & - & - & 3 & 4.48 \\
\hline Manila & - & - & 4 & 21.05 & - & - & 1 & 5.00 & 5 & 7.46 \\
\hline Pasay & - & - & - & - & 1 & 7.14 & - & - & 1 & 1.49 \\
\hline Quezon City & - & - & - & - & 1 & 7.14 & 1 & 5.00 & 2 & 2.99 \\
\hline \multicolumn{11}{|l|}{ Abroad } \\
\hline Bahrain & 1 & 7.14 & - & - & - & - & - & - & 1 & 1.49 \\
\hline China & - & - & - & - & - & - & 1 & 5.00 & 1 & 1.49 \\
\hline \multirow[t]{2}{*}{ Taiwan } & 1 & 7.14 & - & - & - & - & - & - & 1 & 1.49 \\
\hline & 14 & 100.00 & 19 & 100.00 & 14 & 100.00 & 20 & 100.00 & 67 & 100.00 \\
\hline
\end{tabular}

*Note: BSBA - Bachelor of Science in Business Administration (major in Entrepreneurship)

BS Entrep - Bachelor of Science in Entrepreneurship

BSIT - Bachelor of Science in Information Technology

Table 3 presents the work locations of the two batches of graduates (2018 and 2019) for three different courses (BSBA, BS Entrep, and BSIT) of Nueva 'Ecija University of Science and Technology. Results show that majority of the employed graduates are working within the region and mainly in the province of Nueva Ecija.
Specifically, 47 (67.16\%) of the employed graduates are working in different towns / cities in Nueva Ecija, 15 (22.39 $\%)$ are working outside the region (in National Capital Region), and $3(4.48 \%)$ are working abroad like in ahrain, China, and Taiwan.

Table 4. List of Agencies where the Employed Graduates are currently Working

\begin{tabular}{|c|c|}
\hline BSBA / BS Entrep & BSIT \\
\hline 1. K Servico Laur & 1. Puregold \\
\hline 2. Malipampang Elem Sch & 2. SMLI \\
\hline
\end{tabular}




\begin{tabular}{|c|c|}
\hline 3. Motor Trade Cab Burgos & 3. $\quad$ NEUST \\
\hline 4. Taiwan Factory & 4. Provincial Government of Nueva Ecija \\
\hline 5. Motor Trade Palayan & 5. GENEIUS Enterprises \\
\hline 6. K Servico Cabiao & 6. Super Value Inc. \\
\hline 7. Eo Manpower Agency & 7. SPI Global \\
\hline 8. Royce Bongabon & 8. NHGL Phils. Inc. \\
\hline 9. Mayor Ricardo Padilla & 9. $\quad$ Gigahertz Computer System \\
\hline 10. K Servico Bongabon & 10. MPOTECH Digital System \\
\hline 11. Juffair Grand Hotel Bahrain & 11. Pines Seamless Mobile Inc. \\
\hline 12. World Of Fun & 12. Maeda Katsumi \\
\hline 13. Philippine Baterry Inc & 13. Premiere Medical Center \\
\hline 14. Palawan Pera Padala & 14. Leopalace 21 \\
\hline 15. DSWD Cabanatuan & 15. REEL Service Phils, Inc/Amkor Tech. Phils. \\
\hline 16. EXL Service Phils Pasay City & 16. Honda Motors \\
\hline 17. Wheeltek Cabanatuan City & 17. SM Cabanatuan \\
\hline 18. Royce Cabanatuan & 18. Puregold \\
\hline 19. DOLE Palayan City & 19. DOLE \\
\hline 20. BPI Makati City & 20. Sutherland \\
\hline 21. Mercury Drug & 21. JBC Food Corp \\
\hline \multirow[t]{8}{*}{ 22. Puregold Cabanatuan } & 22. Teletech \\
\hline & 23. Shine Nueva Ecija Shine \\
\hline & 24. NEUST-Atate Campus \\
\hline & 25. Professional Regulation Commission \\
\hline & 26. Ideaserv \\
\hline & 27. Kodec Pampanga \\
\hline & 28. Sutherland \\
\hline & 29. National Housing Authority \\
\hline
\end{tabular}

Listed on Table 4 are the agencies where the graduates of Nueva Ecija University of Science and Technology (Atate Campus) are currently working. Some of the following agencies are partner agencies of the NEUST which are composed of private companies, schools, and government institutions.

\section{SUMMARY OF FINDINGS AND RECOMMENDATIONS}

Based from the results of this tracer study, it can be seen that only more than half of the graduates were already employed. The employed graduates are working in their nearby cities/towns and few are working abroad.

It is then recommended by the researcher to have a follow up study on the status of the employment of their graduates. The follow up study should include other information would be beneficial for the improvement of the 
programs and activities related to the graduates of their alma mater, Nueva Ecija University of Science and Technology. A study must include the employed graduates' position in the agency, their challenging experiences while applying on their work, do their current work aligned with their graduated courses, and the like.

This should also include an evaluation of the agencies on the graduates' work attitude and behavior. Thus, evaluating the quality of graduates the university is producing yearly based on the university's mission.

\section{REFERENCES}

[1] Cosser, M. (2003). Graduate tracer study. Technical college responsiveness: Learner destinations and labour market environments in South Africa", HSRC Press, Cape Town.

[2] Creswell, J. W. (2014). A concise introduction to mixed methods research. SAGE publications.

[3] Gines, A. C. (2014). Tracer study of PNU graduates. American International Journal of Contemporary Research, 4(3), 81-98.

[4] Latif, L. A., \& Bahroom, R. (2010). OUM's tracer study: A testimony to a quality open and distance education. ASEAN Journal of Open and Distance Learning, 2(1), 35-47.

[5] Macatangay, L. (2013). Tracer study of BSCS graduates of lyceum of the philippines university from 20042009. Academic Research International, 4(5), 361.

[6] Millington, C. (2008). The use of tracer studies for enhancing relevance and marketability in online and distance education.

[7] NEUST Mission and Vision. (2020). Retrieved from https://neust.edu.ph/index.php/administration/neust-visionmission-tagline-core-values

[8] Philippines Executive Order no. 83, s. 2012, Institutionalization of the Philippine Qualifications Framework

[9] Ramirez, T. L., Cruz, L. T., \& Alcantara, N. V. (2014). Tracer study of RTU graduates: an analysis. Researchers World, 5(1), 66.

[10] Salaria, N. (2012). Meaning of the term descriptive survey research method. International journal of transformations in business management, 1(6), 1-7.

[11] Santos, K. E. S. (2020). Developed Skills of Marketing Students through Direct Selling in Nueva Ecija. Open Access Library Journal, 7(2), 1-5. 